\title{
Calligraphic Elements in Customizing Process of Textiles, Clothes and Clothing Accessories
}

\author{
Viorica Cazac* \\ Faculty of Textiles and Poligraphy, The Technical University of Moldova, Republic of Moldova
}

*Corresponding author: Viorica Cazac, Faculty of Textiles and Poligraphy, The Technical University of Moldova, St. Sergiu Rădăuțanu, 4 MD 2045, Chisinau, Republic of Moldova

submission: 㘹July 14, 2018; Published: 眥 September 26, 2018

\begin{abstract}
The paper presents a study of the possibilities of using calligraphic elements in the customization process of textiles, clothes and clothing accessories. These elements were analyzed considering the relation between the graphic characters, the color scheme, the ideographic ensemble, and the position of the element in correlation with the destination, size and type of the product.
\end{abstract}

The monograms, ideograms, slogans, and phrases presented in 2D or 3D shape are the calligraphic elements used to design different textile products (clothes, technical products and clothing accessories). These calligraphic elements can be reproduced either by weaving, knitting or by a handmade process combined with special graphic technologies: pad and screen printing, thermal printing, as well as varnishing, sublimation, and digital typing. These graphemes are put on different materials by using a special ink compatible with its properties, because it must be resistant while used, washed, rubbed or when exposed to light. The type of ink used in these processes is a thermochromic one because it behaves spectacularly under the influence of the environment conditions (its color changes according to the temperature, it creates special effects and gives off pleasant scents).

Keywords: Calligraphic elements; Compositional elements; Graphic technologies; Special inks

\section{Introduction}

Customization of the products as a big trend today determines current product designers to use new methods and means that would ensure the possibility of diversifying the ensembles of clothing one of these possibilities concerns on the use of calligraphic elements. If once, old calligraphic elements were used more frequent and in modest monograms, today these represent keywords, mottos, oversized visual and communicative expressions, with a sober geometrical or plastic character expressing itself as a compositional centre or creating illusions of texture found in any genre of textiles, clothing, footwear, fashion accessories, furniture products, body art, interior design pieces, cars, etc. The calligraphic manifestation of designers seems to not know demarcations as a field of application and as a character of a surface that it finds itself reproduced, whether they are 2D or 3D surfaces, textile suports, knits, leather, paper, cardboard, non-woven, polymeric supports, metal, etc.

\section{The goal of the study}

Designation of the textiles, clothing, footwear products and fashion-accessories customized by calligraphic assemblies and the study of their aesthetic solutions and technologies.

\section{Materials and Methods}

The study was extended on a sample consisting of textiles, clothing, footwear products and fashion-accessories ornamented with calligraphic ensembles presented in the Figure 1 [1-6].

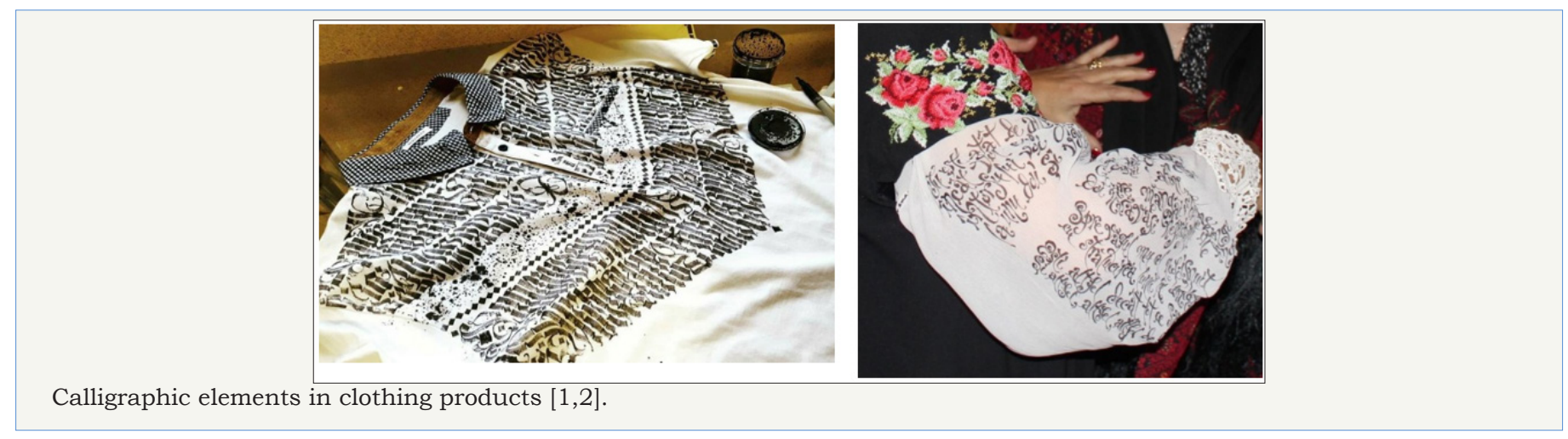


Calvin Klein brand shirts [3].
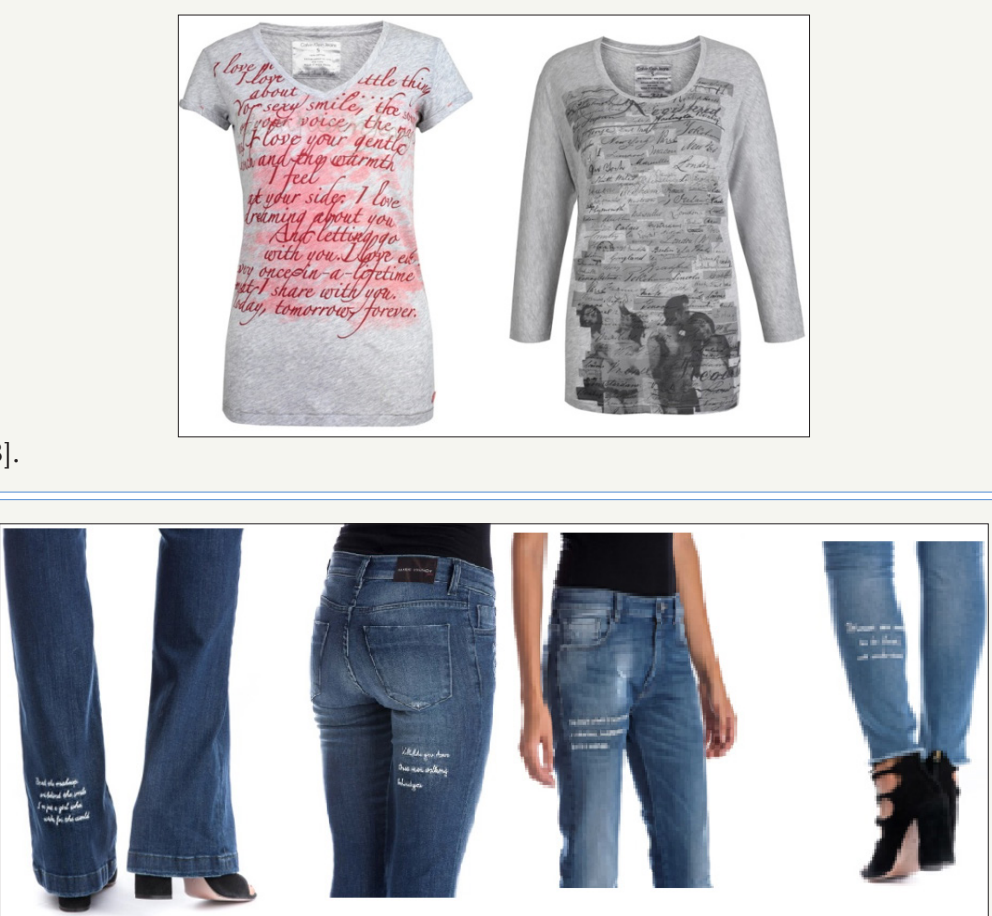

Calligraphy in creation of Cristina Ivanov "Mark Ivanov Jeans" brand [4].

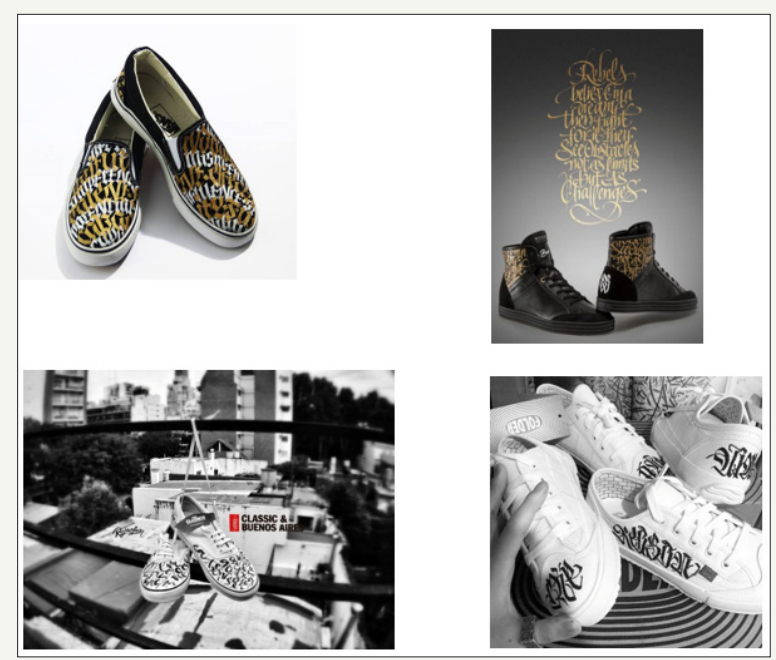

Footwear products decorated with calligraphic elements [5].

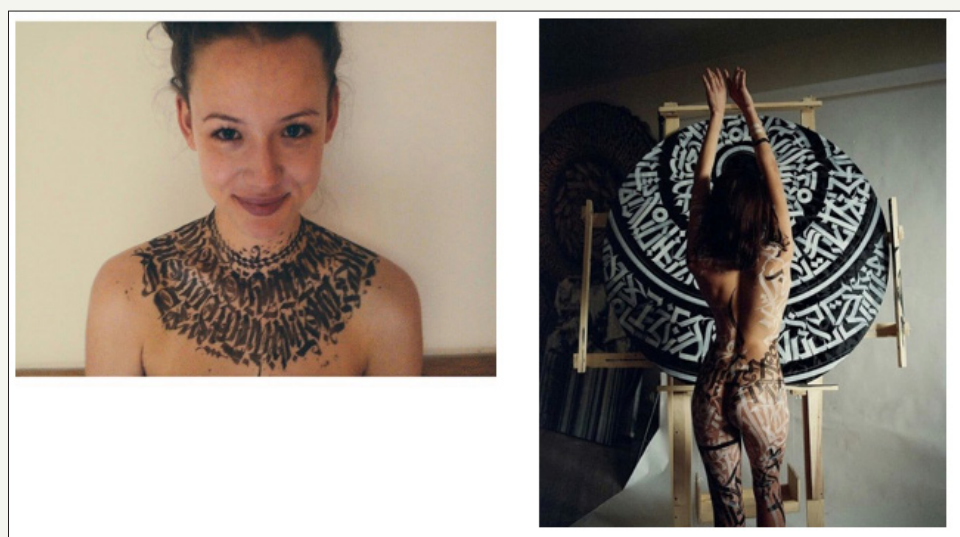

Calligraphic elements in body art [5]. 


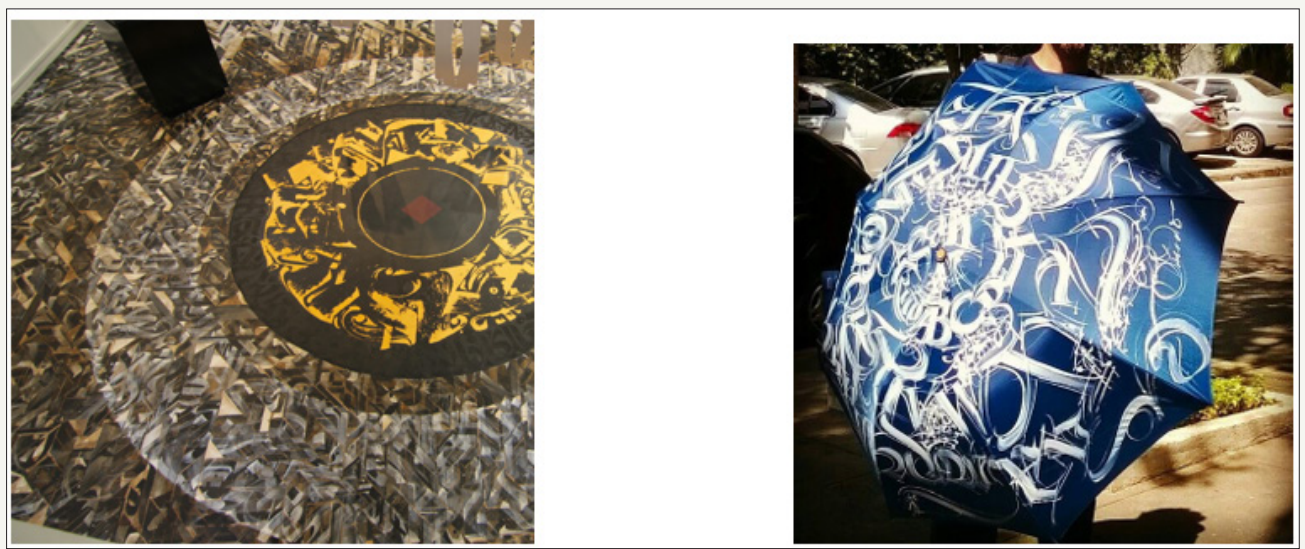

Calligraphic elements in technical products:umbrella [5].
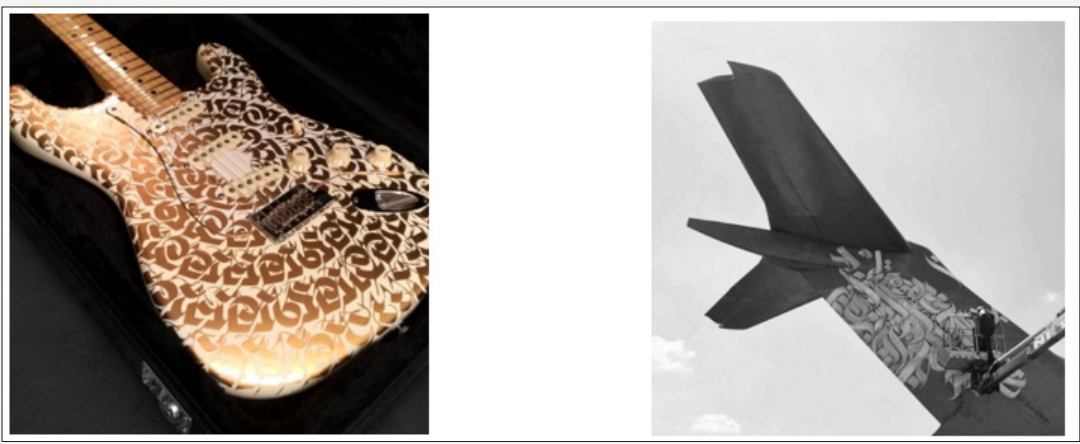

Calligraphic elements in decoration of a guitar and a airplane [5]
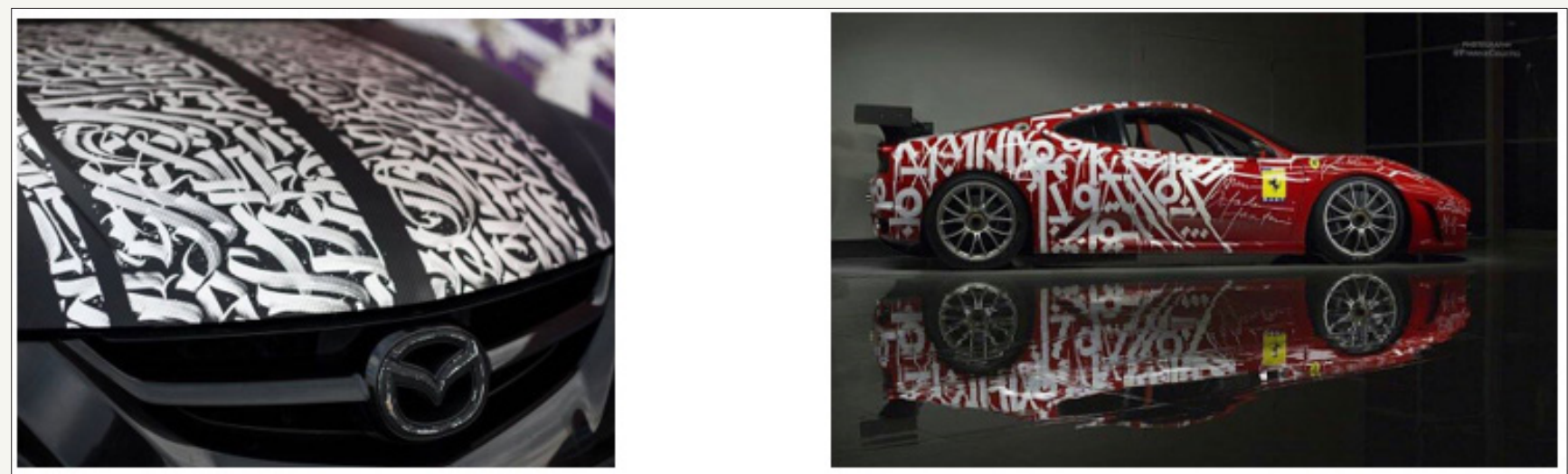

Calligraphic elements in decoration of a car [5].

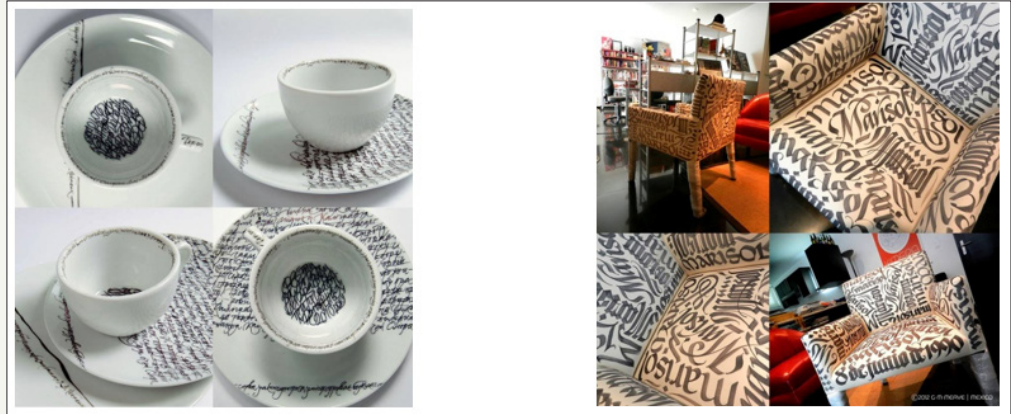

Calligraphy in cookware and furniture [6]. 


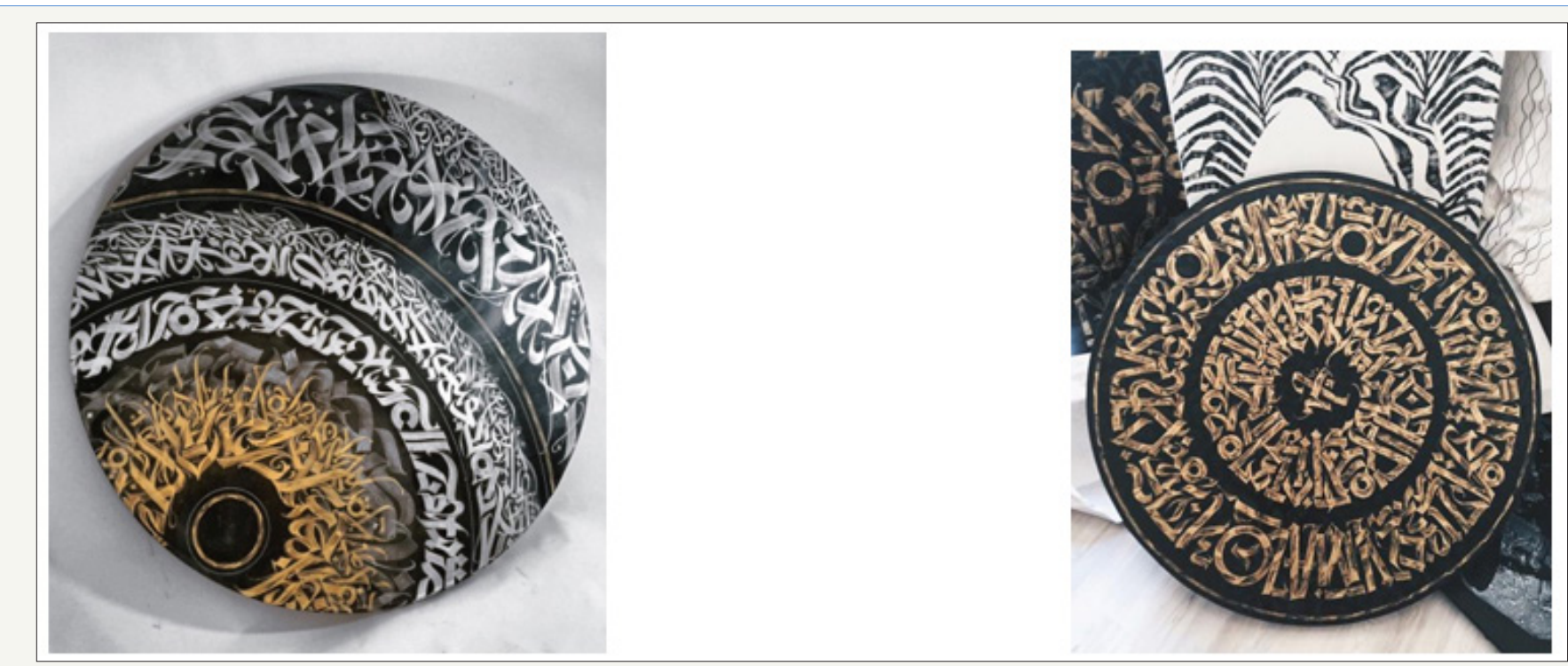

Figure 1: The use of calligraphic elements [5].

Calligraphic elements in interior pieces.

The methods used in research were: participant observation, interpretative method, inductive and deductive, qualitative, comparative, functional structural, analysis and synthesis.

\section{The analysis of calligraphic elements used in clothing, footwear products, fashion-accessories, head covers}

The analysis of calligraphic elements used in aesthetic diveresification of clothing, footwear products and accessories witnessed the use of monograms by 60 's of the XX century. Nowadays the calligraphic processes are represented by keywords, mottos, slogans, aphorisms, logos. The arangement of calligraphic elements that when notice on different directions: vertical, horizontal, oblique, circular, focused on the most nontradiotional areas of products: superior, inferior and central zone catch our attention.

The graphic character of elements can derive from the character of style of the product, developing its geometrical and plastic shape.

The compositional organisation of the calligraphic elements and their incorporation in the clothing, footwear, technical products, fashion-accessories is made similar to execution of calligraphic elements on the paper supports by types of characters from libraries and softwares. Thus, the graphic diversity of analysed calligraphic elements has been structured by the following criteria:
A. after aspect there are:
a) straight graphems;
b) italic graphems;
c) bold graphems;
d) bold-italic graphems.
B. after thickness there are used:
a) white lines;
b) normal lines;
c) half-black lines;
d) black lines;
e) thick lines.
C. after width there are:
a) wide characters;
b) normal characters;
c) narrow characters.

D. after the technology of reproducing the graphic elements there are graphems reproduced by:
a) by weaving;
b) knitting;
c) embroidery;
d) hand made
e) screen printing;
f) sublimation;
g) thermal transfer;
h) electrophographic;
i) templating.

E. after predestination in relation to the diversity of users was found the diversity of ensembles of graphic elements predestinated for (Figure 2), [7-22]: 


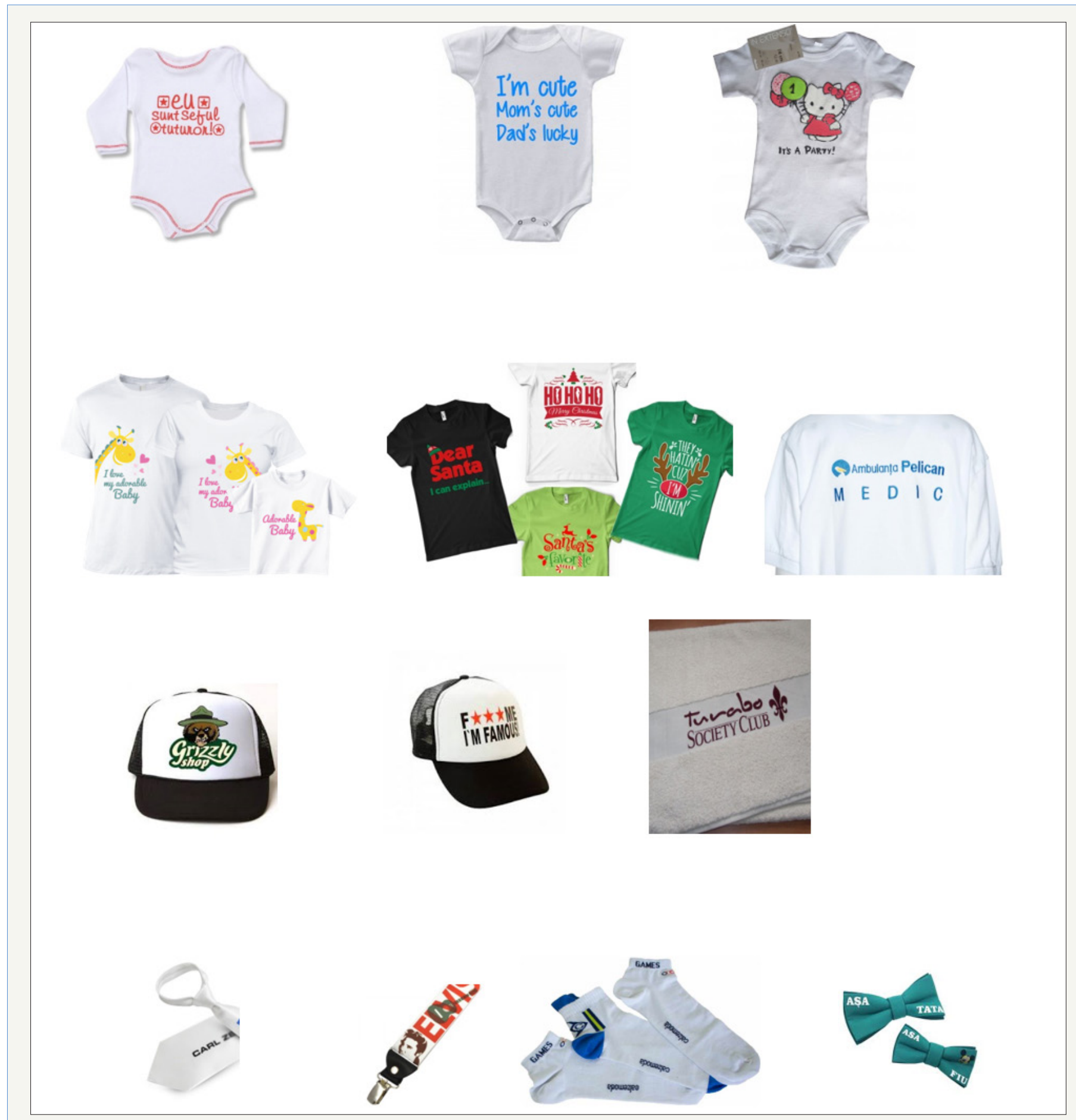

Figure 2: Clothing products decorated with calligraphic elements [6-22].
a) babies;
b) preschool small aged children;
c) high preschool age children;
d) small aged school children;
e) high aged school children;
f) teenagers;

g) young people;

h) adults.

F. after the predestination in relation with the calligraphic objective:
a) everyday products;
b) customized products; 
c) products for specific occasions;

d) uniform.

The analysis of the possibilities of reproducing 2D or 3D calligraphic elements are made from thread, wool or ink with different properties. Raised interest have the inks that allow the conversion of 2D to 3D graphics, thermochromic inks sensitive to changes in ambient temperature which lists ensuring tonal variation of gradational chromatics of the reproduced graphics.

Trends latest integration is the aromatic capsule in inks for printing with an application in various fields and purposes such as the: providing opportunities for identifying thematic materials that are used in clothing products for users with visual impairments, promoting calligraphic elements that invoke different flavors.

\section{Conclusion}

A. Graphical analysis of calligraphic ensembles on the products included in the study has revealed that they are very stylistic identity elements commonly used today as the diversification of clothing and footwear products, clothing accessories, headgear, technical products, etc.;

B. Textual elements reproduced by weaving or knitting are often grotesque graphemes without serifs, the horizontal, vertical, oblique simple arrangement. Reproduced by print are characterized by their plastic, the display of serifs, layouts on complex trajectories, their integration with printed illustratitve graphics;

C. The use of textual elements are not only decorative but also cognitive functions, informative, of spiritual identity of the user, customization;

D. Functional diversification of textual elements is made possible with the help of special printing inks: thermochromic, flavored, etc.

\section{References}

1. http://www.larevista.ro/anca-ciuciulin-caligrafia-e-calea-mea-de-relaxare-si-de-meditatie/
2. https://web.facebook.com/Calligraffiti-349261328227/?fref=ts

3. http://www.4shopping.ru/collection/calvin-klein-jeans-fall-winter-12-13-4867/

4. http://www.tramway.org/events/Pages/Costume-Written-Clothing. aspx/

5. https://www.google.com/search?q=ciorapi+personalizati\&biw

6. http://archvuz.ru/2014_2/18/

7. http://www.tea-coffee.ro/ceaiul/juuni-hitoe-rafinament-in-douasprezece-straturi/

8. http://japoneza.com/ro/caligrafie

9. http://fason.club/2016/05/novaya-kollektsiya-ukrashenij-kalligrafiya-yuvelirnogo-brenda-alhimiya-alchemia-jewellery/

10. http://www.scritub.com/literatura-romana/carti/EMILIA-DROGOREANU-Influente-al121139191.php/

11. http://diez.md/2016/03/07/foto-povestea-tinerei-din-moldova-caresi-a-creat-un-brand-de-blugi-in-italia./

12. https://books.google.md/books?id=jvpwygq9i3UC\&pg=PA1\&lp$\mathrm{g}=\mathrm{PA} 1 \& \mathrm{dq}=$ written+clothing $\&$ source $=\mathrm{bl} \&$ ots $=\mathrm{kMXXaXCS3r} \&$ sig $=\mathrm{clp}-$ $\mathrm{SA} /$

13. http://studydoc.ru/doc/4522836/2.1-\%C2\%ABe-volyuciya\%C2\%BB-nadpisej-na-odezhde/

14. http://www.poisk-ru.ru/s16489t2.html/

15. http://www.uchportal.ru/publ/23-1-0-4504/

16. https://www.theknot.com/content/wedding-invitation-trends/

17. http://blog.tshirt-factory.com/how-to-start-a-t-shirt-business-in-5-basic-steps.html\#.V67EIa2X9W0/

18. http://www.livingwell.jo/content/cover-story/jordan\%E2\%80\%99s-faces-fashion/

19. http://www.zazzle.com/calligraphic+kids+clothing/

20. http://my.asiatatler.com/fashion-beauty/beauty/montblanc-legend-calligraphy-limited-edition-fragrance/

21. http://www.indymedia.be/index.html\%3Fq=node\%252F2967.html/

22. http://www.paratype.ru/e-zine/defis_08/index3.html/
Creative Commons Attribution 4.0 International License

For possible submissions Click Here

\section{Submit Article}

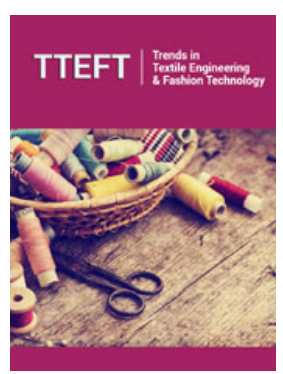

Trends in Textile Engineering \& Fashion Technology

\section{Benefits of Publishing with us}

- High-level peer review and editorial services

- Freely accessible online immediately upon publication

- Authors retain the copyright to their work

- Licensing it under a Creative Commons license

- Visibility through different online platforms 